\title{
Program Adiwiyata Membentuk Perilaku Cinta Lingkungan Warga SMPN 2 Colomadu
}

\author{
Rashyid Muttaqim Maulana ${ }^{1)}$, Kuny Hidayah ${ }^{2)}$ \\ 1,2,3) Universitas Muhammadiyah Surakarta \\ a610180043@ums.ac.id \\ doi: $10.23917 /$ blbs.v2i1.11609
}

\begin{abstract}
Abstrak. SMPN 2 Colomadu mendapatkan penghargaan dari pemerintah sebagai sekolah adiwiyata tingkat nasional pada tahun 2019. Program ini mengajak warga sekolah berpartisipasi aktif dalam menjaga dan merawat lingkungan. Partisipasi yang diterapkan oleh warga SMPN 2 Colomadu berupa kegiatan yang ramah lingkungan. Kegiatan yang dilakukan antara lain memilah sampah organik dan anorganik, bank sampah, pengolahan pupuk kompos, jum'at sehat dan bersih, penanaman tanaman hidroponik, biopori, pemanfaatan limbah air wudhu untuk pengairan kolam ikan, jajanan kantin bebas dari plastik, dan RPP diselipkan konsep adiwiyata. Program adiwiyata ini tidak hanya dilakukan di dalam sekolah, tapi juga dilakukan di luar lingkungan sekolah. Penerapan budaya cinta lingkungan mengikutsertakan masyarakat sekitar untuk peduli terhadap lingkungan. Hasil program adiwiyata di sekolah membentuk sekolah imbas di sekitar SMPN 2 Colomadu.
\end{abstract}

Kata Kunci: Adiwiyata, Lingkungan, Peduli Lingkungan

\section{PENDAHULUAN}

Kerusakan lingkungan merupakan masalah serius yang dihadapi dunia saat ini. Kerusakan lingkungan disebabkan oleh dua faktor, kerusakan lingkungan akibat peristiwa alam dan akibat aktivitas manusia. Masalah lingkungan yang sungguh memprihatinkan seperti perubahan iklim global, pengelolaan limbah, kelangkaan air, ledakan penduduk, menipisnya sumber daya alam, kepunahan tumbuhan dan hewan, kerusakan habitat alam, dan peningkatan polusi serta kondisi lingkungan yang dari waktu ke waktu terus mengalami penurunan merupakan bukti dari semakin rusaknya lingkungan bumi. Dari berbagai masalah tersebut, maka mencintai lingkungan merupakan kebutuhan yang tidak bisa ditunda.

Menumbuhkan budaya cinta lingkungan khususnya dikalangan peserta didik diharapakan dapat menjadi salah satu alternatif solusi dari banyaknya masalah lingkungan yang terjadi. Peserta didik yang memiliki sikap, perilaku dan budaya cinta lingkungan hidup diharapkan dapat menjadi wadah perubahan 
dan kelak mereka pun akan menjadi pengambil kebijakan mengenai cara pengelolaan lingkungan hidup yang baik. Sekolah dianggap sebagai tempat yang tepat dan efektif untuk menumbuhkan nilai-nilai budaya dan menanamkan kesadaran cinta lingkungan hidup, karena sekolah merupakan tempat peserta didik memperoleh pendidikan dimana proses pendidikan berlangsung dengan tujuan untuk mengubah tingkah laku ke arah yang lebih baik.

Menumbuhkan kecintaan terhadap lingkungan pada peserta didik harus mulai dilakukan sejak awal pembelajaran. Materi tentang pendidikan lingkungan hidup sudah semestinya diberikan kepada peserta didik pada masa pengenalan sekolah sebagai kegiatan penanaman pondasi budaya cinta lingkungan. Penanaman budaya cinta lingkungan yang dilakukan sejak awal merupakan suatu upaya generasi agar yang akan datang semakin menyadari akan pentingnya menjaga kelestarian lingkungan hidup. Selain itu, demi tercapainya lingkungan yang bersih dan nyaman untuk belajar, maka diperlukan langkah-langkah untuk melestarikan lingkungan yang dapat dilaksanakan melalui program Adiwiyata.

Menurut Muhammad Dendy F (2017:29) latar belakang dibentuknya program adiwiyata yaitu mempercepat pengembangan pendidikan lingkungan hidup ditingkat sekolah dasar hingga tingkat sekolah menengah atas di Indonesia. Harapan pemerintah dengan dibentuknya program Adiwiyata dapat realistis diwujudkan, karena pendidikan lingkungan hidup merupakan mata pelajaran yang penerapannya dapat diwujudkan langsung dalam kehidupan sehari-hari, baik di lingkungan sekolah, di lingkungan tempat tinggalnya maupun di lingkungan. Dimanapun individu itu berada peduli terhadap lingkungan merupakan perilaku yang menerapkan budaya cinta lingkungan. Budaya cinta lingkungan dapat dibentuk melalui pembiasaan yang dilakukan sesering mungkin oleh individu terhadap lingkungan sekitar. Dalam dunia pendidikan, budaya cinta lingkungan telah ditanamkan kepada peserta didik yang diarahkan untuk mencintai dan menjaga lingkungan sekolah dan 
sekitar agar terciptanya lingkungan yang bersih dan nyaman dalam proses kegiatan belajar mengajar. Sekolah merupakan tempat yang strategis untuk meningkatkan pengetahuan lingkungan siswa (Potter, 2010). Melalui program adiwiyata yang diberikan pemerintah berupa penghargaan terhadap sekolah yang peduli terhadap lingkungan, warga sekolah dihimbau untuk berpartisipasi dalam perlindungan dan pengelolaan lingkungan hidup. Pemerintah melalui Kementerian Lingkungan Hidup dan Kehutanan memberikan apresiasi berupa penghargaan untuk sekolah yang peduli terhadap lingkungan sebagai sekolah adiwiyata. Program ini bukan suatu lomba yang harus diperebutkan, namun program ini bentuk pengakuan bahwa sekolah yang mendapatkan penghargaan adiwiyata dapat menjaga lingkungannya dan menerapkan budaya cinta lingkungan berupa tindakan ramah lingkungan dalam hal penanaman tanaman, pengelolahan sampah, dan mencari alternatif terhadap masalah lingkungan yang ada di sekitar. Artikel ini dibuat dengan tujuan untuk mengetahui perilaku peduli cinta lingkungan warga SMPN 2 Colomadu dan mengetahui dampak program adiwiyata yang dilaksanakan sekolah terhadap warga SMPN 2 Colomadu.

\section{METODE PENELITIAN}

a. Tempat Dan Waktu Pelaksanaan

1) Tempat Tempat penelitian ini dilaksanakan di SMPN 2 Colomadu

2) Waktu Pelaksanaan

Observasi dilakukan pada tanggal 28 Januari - 11 Februari 2020 di SMPN 2 Colomadu

b. Populasi

Populasi dalam observasi ini adalah warga SMPN 2 Colomadu

c. Jenis Penelitian

Penelitian yang digunakan menggunakan metode penelitian survei deskriprif, dimana bermaksud untuk mengumpulkan data atau informasi mengenai sekolah menuaggunakan sampel yang lebih kecil. Lokasi penelitian di SMPN 2 Colomadu berlokasi di Nanasan, Malangjiwan, Kecamatan Colomadu, Kabupaten Karanganyar Jawa Tengah. Waktu penelitian dilakukan pada : 28 Januari - 10 Februari 2020, Pukul 07.00 - 14.00. Penelitian ini melibatkan seluruh warga 
SMPN 2 Colomadu. Teknik pengumpuan data menggunakan teknik observasi, wawancara.

\section{HASIL PENELITIAN DAN PEMBAHASAN}

Hasil dan pembahasan dari observasi yang diamati peneliti di lingkungan sekitar SMPN 2 Colomadu adalah sebagai berikut.

Program adiwiyata melibatkan semua komponen yang ada di sekolah. Warga SMPN 2 Colomadu menerapkan pembiasaan berupa membuang sampah pada tempatnya. Tempat sampah yang disediakan di sekolah terdapat dua jenis, yaitu organik dan anorganik. Penyediaan dua jenis tempat sampah ini bertujuan agar warga sekolah dapat memilah jenis sampah yang dibuang sesuai dengan jenisnya. Pembiasaan membuang sampah sesuai dengan jenisnya merupakan suatu langkah awal baik yang dilakukan oleh warga sekolah. Dengan membuang sampah pada tempatnya dan sesuai dengan jenisnya, warga sekolah dapat menjaga kebersihan lingkungan sekolah agar terciptanya lingkungan yang asri.

Lingkungan yang asri itu lingkungan yang terbebas dari sampah, terutama sampah plastik. SMPN 2 Colomadu melakukan pengurangan penggunaan sampah plastik pada lingkungan sekolah dan sekitarnya. Contohnya pada penjual makanan di kantin SMPN 2 Colomadu yang melakukan pengurangan penggunaan sampah plastik. Penjual menyediakan wadah seperti piring, mangkok, dan gelas agar warga sekolah yang membeli dapat menikmati makanan tanpa harus khawatir dengan timbulnya sampah. Warga sekolah dapat menikmati makanan di kantin maupun lingkungan sekolah. Jajanan ringan seperti cilok, gorengan, bakso bakar, sosis dapat di wadahi dengan piring kecil dan mangkok kecil. Minuman seperti es, kopi, teh dapat diwadahi dengan gelas yang disediakan penjual. Sebelum makan budaya mencuci tangan sebelum makan ini terlaksana oleh warga sekolah. Fasilitas yang di sediakan oleh sekolah berupa westafel yang berada di setiap ruangan menjadikan seluruh warga sekolah mudah dalam menjangkau air saat ingin makan dan setelah makan. Setelah makan dan minum, wadah dapat dikembalikan ketempat penjualnya. Selain 
itu siswa diminta untuk membawa wadah makan dan minum sendiri, agar mengurangi sampah plastik di sekolah. Hal ini menjadikan tempat sampah yang ada di lingkungan sekolah lebih banyak berisi sampah organik atau sampah yang lebih mudah di daur ulang.

Sampah organik atau sampah yang dapat didaur ulang ini seperti dedaunan, sisa makanan, kertas, tisu. Sampah dedaunan dan sisa makanan dapat diolah menjadi pupuk kompos. Proses pembuatan pupuk kompos ini dilakukan di sekolah yang berlokasi di samping aula SMPN 2 Colomadu. Pupuk kompos yang sudah jadi akan menjadi pupuk untuk tanaman di lingkungan SMPN 2 Colomadu. Selain sampah dedaunan, sampah yang tersisa seperti kertas dan tisu dapat di tukar menjadi uang di bank sampah SMPN 2 Colomadu. Hasil yang di dapat dari bank sampah kemudian masuk ke dalam kas kelas masing-masing. Kegiatan ini dilakukan setiap hari jum'at pada kegiatan jum'at bersih. Kegiatan jum'at bersih ini yaitu sebelum kelas dimulai, seluruh siswa membersihkan kelas dan lingkungan sekitar kelas masing masing. Mulai dari menyapu kelas, mengepel lantai, membersihkan kaca jendela, menyiram tanaman yang berada di depan kelas, merawat tanaman hidroponik, sampai menimbang sampah yang berada di depan kelas kemudian menyetor di bank sampah. Setelah kegiatan tersebut selesai, dilanjutkan dengan kegiatan belajar mengajar yang nyaman karena lingkungan sekitar menjadi bersih.

Lingkungan SMPN 2 Colomadu memiliki lubang biopori yang bertujuan untuk menambah daerah resapan air disekolah. Lubang biopori dibuat secara vertikal kedalam tanah yang berisi bahan organik. Bahan organik yang berada di lubang ini berperan sebagai sumber energi fauna yang berada di dalam tanah yang sedang melakukan aktivitas membentuk biopori. Lubang ini untuk daerah resapan air yang berfungsi untuk mengatasi genangan air. Air hujan akan terserap oleh lubang sehingga mengurangi bahaya banjir yang terjadi di sekolah. Pembuatan lubang biopori ini dilakukan melibatkan siswa SMPN 2 Colomadu.

Pengenalan peduli lingkungan ini dilakukan agar menjadi bekal siswa di hari kemudian dalam mengatasi masalah lingkungan. Manfaat yang dihasilkan berupa meningkatkan 
daya resapan air, mengubah sampah organik menjadi kompos, mengurangi emisi gas rumah kaca, memanfaatkan aktivitas fauna dan akar tanaman, mengatasi penyakit yang timbul akibat genangan air. Air juga dapat terserap dengan adanya tanaman-tanaman. Tanaman di lingkungan SMPN 2 Colomadu cukup banyak. Warna hijau yang terpancar di sekolah ini membuat mata menjadi fresh saat memandang lingkungan sekolah. Budidaya tanaman yang ada di SMPN 2 Colomadu terdapat tanaman yang besar hingga yang kecil. Ada juga budidaya tanaman hidroponik yang dibuat setiap kelas.

Pemanfaatan mata pelajaran seni budaya, siswa diminta untuk membuat kreasi dengan memanfaatkan barang bekas seperti botol plastik. Kemudian botol tersebut dikreasikan menjadi wadah tanaman hidroponik. Tanaman kemudian dimasukan ke wadah yang sudah dibuat oleh siswa. Hasil karya mereka di letakan menggantung di depan kelas sebagai hiasan siswa di depan kelas. Kemudian siswa menjaga dan merawat tanaman tersebut agar dapat merasakan kesegaran udara yang diberikan oleh tanaman tersebut. Selain dalam pelajaran seni budaya, pembentukan perilaku cinta lngkungan dapat dimasukkan kedalam rencana pelaksanaan pembelajaran pada mata pelajaran yang lain. Contohnya seperti mata pelajaran bahasa inggris, "Please Don't Litter". Kalimat ini menunjukan himbauan jangan membuang sampah sembarangan. Hal ini sekaligus merupakan suatu ajakan kepada siswa agar siswa dapat menjaga kebersihan dengan membuang sampah pada tempatnya sesuai dengan jenis sampahnya. Sebelum pelajaran dimulai, guru SMPN 2 Colomadu menanyakan "apakah ada sampah dikolong meja? Jika ada, harap dibuang terlebih dahulu". Hal ini berguna untuk kenyamanan dalam proses belajar mengajar di kelas. Jika kelas bersih, poses belajar mengajar menjadi tidak terganggu.

Kegiatan di SMPN 2 Colomadu ini selain belajar, ada waktu untuk sholat berjamaah saat dzuhur. Seluruh warga sekolah berbondong-bondong mengambil air wudhu saat akan memasuki waktu sholat. Banyaknya warga sekolah SMPN 2 Colomadu menjadikan kebutuhan air untuk wudhu yang cukup banyak juga. Namun SMPN 2 Colomadu menerapkan sistem 
penggunaan air yang efektif dan efisien. "Air wudhu yang sudah dipakai ini, kami alirkan ke kolam ikan mbak untuk mengganti air di kolam ikan, jadi air tidak terbuang sia sia." Kata pak Slamet Widodo, Wakil Kepala SMPN 2 Colomadu. Pak Slamet Widodo menjelaskan air wudhu yang digunakan tidak dibuang begitu saja, melainkan limbah air wudhu dialirkan ke kolam ikan yang berada di sekolah untuk kehidupan ikan di kolam tersebut. Limbah air wudhu tidak mengandung bahan kimia apapun, sehingga aman dikonsumsi untuk ikan yang berada di kolam ikan. Sekolah adiwiyata memiliki sekolah imbas. Sekolah imbas yang dimaksud merupakan sekolah yang berada dalam satu wilayah yang menerapkan prinsip yang sama dengan sekolah adiwiyata. Jadi, siswa dan guru SMPN 2 Colomadu juga menanam tanaman di beberapa sekolah sekitar SMPN 2 Colomadu. Agar sekolah imbas tersebut juga dapat menjadi sekolah yang peduli terhadap lingkungan.

\section{SIMPULAN}

Program Adiwiyata berperan penting dalam pembentukan perilaku cinta lingkungan siswa dan warga SMPN 2 Colomadu. Di dalam tujuan dari program adiwiyata ini menggunakan semua komponen dan elemen yang berada di sekolah, seperti kegiatan, kurikulum, sarana dan prasarana, dan kebijakan. Sekolah diarahkan untuk mengembangkan lingkungan hidup yang sehat, siswa yang cerdas, kreatif dan inovatif serta memiliki tingkat kepedulian tinggi terhadap kelestarian lingkungan baik di dalam sekolah maupun di luar sekolah. Program ini melibatkan seluruh warga sekolah, mulai dari siswa, guru, staff karyawan, kepala sekolah, petugas kebersihan, hingga pedagang yang berada di lingkungan sekolah. Hal ini memberikan kesadaran bagi warga sekolah akan pentingnya peduli terhadap lingkungan. Dampak dari peduli terhadap lingkungan memberikan efek nyaman dalam melakukan aktivitas di lingkungan sekitar, terhindar dari polusi udara, terhindar dari penyakit yang membahayakan, terhindar dari bencana seperti banjir. 


\section{DAFTAR PUSTAKA}

Rakhmawati, Darning dkk. (2016).Peran Program Adiwiyata dalam Pengembangan Karakter Peduli Lingkungan Siswa: Studi Kasus di SMK Negeri 2 Semarang. 5(1), 1057-1190.

Hadi, Djati Witjaksono. (2017). Tumbuhkan Generasi Cinta Lingkungan Melalui Sekolah Adiwiyata. Diakses dari www.menlhk.go.id/site/single post/265.

Bahrudin, Mohammad Dendy Fathurahman. (2017). Pelaksanaan Program Adiwiyata dalam Mendukung Pembentukan Karakter Peduli Lingkungan di SMA Negeri 4 Pandeglang. 17(1), 25-37. 